\title{
TANÁRKÉPZÉSÜNK REFORMJÁRÓL NÉGY ÉV UTÁN, ÉS BENNE ÚJRA A SZAKMÓDSZERTANOKRÓL, SZAKDIDAKTIKÁRÓL
}

\section{KATONA ANDRÁS}

az Eötvös Loránd Tudományegyetem Bölcsészettudományi Karának

főiskolai docense,

a Tanárképzők Szövetsége Szakmódszertani Szakosztályának

ügyvezető elnöke

kato@ludens.elte.hu

Keserü hangú hozzászólást írtam a témában a Pedagógusképzés 2007. 1. számában, melynek lényege az volt, hogy az egységes kétciklusú tanárképzés bevezetése elkapkodott, kellően át nem gondolt, rengeteg kárt okozhat, főleg az ún. közismereti tárgyak képzésében. Politikai és lobbiérdekek nyomán született a döntés (a tanítóképzés például teljesen kimaradt a reformból), melynek hátterében munkaerőpiaci megfontolások munkáltak, vagyis a csökkenő gyerekszámhoz kevesebb tanár képzésére van szükség. Ez - különösen a természettudományos tanárképzésben - „túl jól sikerült".

Kasszandrának érezhetem magam, hisz jóslataim szinte mind beváltak, de ellenérveim nem találtak meghallgatásra, hiszen ma is aktuális kérdéseimet az illetékesek válaszra sem méltatták. És ha én lettem voltam az egyetlen ellenző? Sokan voltunk ilyen Kasszandrák. Mire nem érkezett válasz?

- Szinte semmire sem jó a BA-s diploma, amennyiben a végzett nem lép tovább a mesterképzésbe, melynek felvételi kerete erősen limitált, harmada az alapképzésnek. Ez így nem más, mint a munkanélküliek létszámának csökkentése a felsőoktatásban való ,parkoltatással”.

- A tanári mesterségre, professzióra szocializálni kell, mégpedig a képzés első napjától, de mindenképpen az elejétől. Ehhez képest az első három év szinte teljesen csak a szaktárgyról szól. Nem érv, hogy a 18 évesek még nem tudnak dönteni, mert három év múlva döntésük éppen annyira esetleges, tapasztalatok híján való.

- Amennyire örvendetes a képzés végére beiktatott fél éves gyakorlat, anynyira nevetséges, hogy jövőre tanárok tömege kaphat diplomát januárfebruárban, amivel nyilván minimum hónapokig semmit sem tud majd mit kezdeni. De ez már 2006-ban is látható volt! 
A „pusztába kiáltott” kérdésekhez azóta új, és eléggé egységesen szomorú tapasztalatok csatlakoztak. Abból a kényszerből, hogy a szakos képzés az első három évre összpontosul, az a gyakorlat született, hogy például történelemböl három év alatt kell elvégezni a hallgatóknak a teljes anyagot, amire eddig a föiskolákon is négy év állt a rendelkezésre. Ez mindenképpen színvonaleséshez vezet!

A mesterképzés két évében viszont a pedagógiai-pszichológiai tárgyak dominálnak, lényegesen nagyobb óraszámokkal, mint a korábbi tanárképzés rendszerében. Értem én, hogy a megnövekedett nevelési problémák fokozottabb felkészítést igényelnek, de milyen tekintélye lesz a kellő szaktárgyi ismeret híján lévő tanároknak? Láttam már - igaz, jellemzően a felsőoktatásban és kevéssé a közoktatásban kiváló tanárt kellő pedagógiai képzettség híján; de magas pedagógiai képzettséggel rendelkező, képzetlen szaktanárt még nem! És nem is szeretnék! Sajnos, a gyanúm az, hogy itt is a lobbiérdekek döntöttek, hiszen amennyire egységes pedagógiaipszichológiai képzők társadalma hazánkban, annyira széttöredezett a különböző szakterületeket, szaktárgyakat tanító tanároké.

Hogy saját szükebben vett szakterületemről, a szakmódszertanról is szóljak, mi szakmódszertanosok a két szék közül (szaktárgyi és pedagógiai-pszichológiai képzés) a pad alá kerültünk. Ez már négy évvel ezelőtt is látható volt, hogy így lesz. A szakmai és tanárképzési kreditekért folyó ,óriások csatájá”-ban nekünk csak morzsák jutottak. Gyakorlatilag ugyanannyi, mint amennyi korábban volt, csakhogy mostmár bevallottan az általános iskolai és középiskolai szaktanárságra is fel kell készíteni, itt most utóbbin belül halványan megemlítve a speciálisabb igényeket kívánó szakközép-, és az igazán „spéci” területet jelentő szakiskolát is. Nem beszélve szakterületem, szaktárgyam azon sajátosságáról, hogy történelemtanítás mellett a társadalmi ismeretek, jelenismereti stúdiumok tanításának sajátos feladataira is fel kell készíteni a jövendő tanárokat. Négy éve azt írtam, hogy „aggódom az általános iskolai tanárképzés jövője miatt”. Azóta jól látom, hogy a középiskolai történelemtanítás is paradigmaváltáson megy keresztül az új érettségi rendszer miatt, ami az e terület iránt való fordulást igényelné, tehát csak azt dönthetem el, hogy melyik ujjamat vágjam meg.

Mit tehetünk a jelen helyzetben? Erre kereste a választ a Tanárképzők Akadémiájának V. ülése, melyen a köztársasági elnök számára készített Szárny és teher szakanyag készítői ( $D r$. Csermely Péter) és más elkötelezett felsőoktatási szakemberek (Dr. Hatvani László és Dr. Patkós András) álltak elő bölcs javaslatokkal. Ezt aztán az utána hozzászóló pedagógiai-pszichológiai szakemberek többsége lesöpörte az asztalról, a bevezetésért első számú felelős azt hangoztatva, hogy nincs elég tapasztalat. Hunyady Tanár Úrnak ezúton is jelentem, igenis van. Ebből kötöttem egy szerény csokrot, mert a helyzet teljességgel tarthatatlan. És ez nem csupán a magánvéleményem! Körül kell nézni például intézményem, az ELTE Bölcsészetés Természettudományi Karán! 
Persze azt is tudom, hogy elhamarkodott és hibás döntéseket csak tetézni lehet ellenkező előjelü hasonlókkal. Szerényen és minden visszhang nélkül elhangzott egy javaslat ezen a tanácskozáson, ami tárgyalási alapul szolgálhatna a továbbiakhoz: egy évvel megnövelni a tanárképzés időtartamát az állami támogatás (fejpénz) emelése nélkül. Ha ezt ki tudnánk tölteni kellö tartalommal, de a szaktárgyakat és a szaktárgyi módszertanok képviselőit is egyenlő partnernek tekintve a pedagógiaipszichológiai tárgyakéval, akkor menthetnénk a jelenlegi, az eredményes tanárképzés jövőjét erősen fenyegető helyzetet. Mert igenis vészhelyzet van! 